\title{
Plumeria rust caused by Coleosporium plumeriae on frangipani trees in Sumatra, Indonesia
}

\author{
Leonardo Sarno Soares Oliveira $^{1} \cdot$ Eko Sulistyono $^{2} \cdot$ Pantun David Mangatas Lbn Gaol $^{1} \cdot$ Tisha Melia $^{2} \cdot$ Alvaro Durán $^{1}$
}

Received: 21 July 2019 / Accepted: 25 October 2019 / Published online: 12 November 2019

(C) Australasian Plant Pathology Society Inc. 2019

\begin{abstract}
Powdery rust pustules of bright yellow-orange color were observed forming on both mature and young leaves of red frangipani (Plumeria rubra) in the province of Riau, Sumatra, Indonesia. Based on morphological characteristics and DNA sequence of the internal transcribed spacer region (ITS), the rust fungus was identified as Coleosporium plumeriae, only urediniospores were found on the infected leave. Inoculation trials confirmed the pathogenicity of $C$. plumeria, fulfilling the Koch's postulates. This is the first report and characterization of plumeria rust caused by C. plumeria on frangipani on the island of Sumatra, Indonesia.
\end{abstract}

Keywords Rust disease $\cdot$ Flowering plants $\cdot$ Urediniospores $\cdot$ Temple tree

Plumeria spp. are flowering plants of the family Apocynaceae, with center of origin in West Indies and Central America, but widely cultivated in other tropical and sub-tropical areas, especially in Asian countries and the Pacific Islands (Nelson 2009). In Indonesia, Plumeria spp. are commonly found in urban landscapes or as potted plants, especially in the island of Bali. Their flowers are associated with the Balinese culture and the plants are locally named as frangipani, temple tree, "kamboja" or "jepun".

Kobayashi et al. (1994) reported P. rubra plants (red frangipani) found suffering from a serious rust disease caused by Coleosporium plumeriae, and this is considered the first official report of this disease in Indonesia. The disease was subsequently reported in the same plant species in West Java (Kakishima et al. 2017). Coleosporium plumeriae Pat. (Patouillard 1902) belongs to the Family Coleosporiaceae (Pucciniales). It was originally reported on $P$. alba plants in Santo Domingo, West Indies, in 1852 as Uredo domingensis Berk. (Arthur 1918). This disease is now known to have a worldwide distribution. The reason for its unexpected and

Leonardo Sarno Soares Oliveira leonardo_oliveira@aprilasia.com

1 Plant Health Program, Research and Development, Asia Pacific Resources International Holdings Ltd. (APRIL), Pangkalan Kerinci, Riau 28300, Indonesia

2 Molecular Biology and Genomics Program, Research and Development, Asia Pacific Resources International Holdings Ltd. (APRIL), Pangkalan Kerinci, Riau 28300, Indonesia rapid expansion from Central America to Pacific Islands remains unclear but has been hypothesized to be related to human-mediated introductions and also due to climate changes related to El Niño and La Niña events in the Pacific Ocean (Kakishima et al. 2017).

P. rubra has been widely planted in the Indonesian territory but there are no official reports of plumeria rust from Sumatra, the largest island that is located entirely in Indonesia. The aim of this study was thus to report and characterize the morphology, pathogenicity and DNA profile of Coleosporium plumeriae from Riau, Sumatra, Indonesia.

Numerous powdery rust pustules (uredinia) were observed forming on the abaxial surface of both mature and young leaves (Fig. 1). No symptoms were observed on flowers, stems or branches. As the disease progressed, coalescent pustules could be observed on the upper leaf surface as sunken, angular, yellowish flecks or even necrotic lesions. In case of severe infection, curly and distorted leaves were observed followed by defoliation.

In September 2018, infected leaves of P. rubra showing rust symptoms were collected from urban trees located in Pangkalan Kerinci, Riau, Indonesia (coordinates: $0^{\circ} 24^{\prime} 0^{\prime \prime}$ $\mathrm{N}, 101^{\circ} 51^{\prime} 0^{\prime \prime} \mathrm{E}$ ). A total of sixteen samples were analyzed at the RGE Plant Pathology Laboratory (Pangkalan Kerinci). With the aid of a soft brush, urediniospores were collected from infected leaves and stored in glycerol $15 \%$ at $-80{ }^{\circ} \mathrm{C}$. Additionally, a representative specimen was selected and deposited in the culture collection of Bogor Agricultural University (IPB/LIPI -Accession number: 243234). For examination of morphological features, uredinia were mounted in 

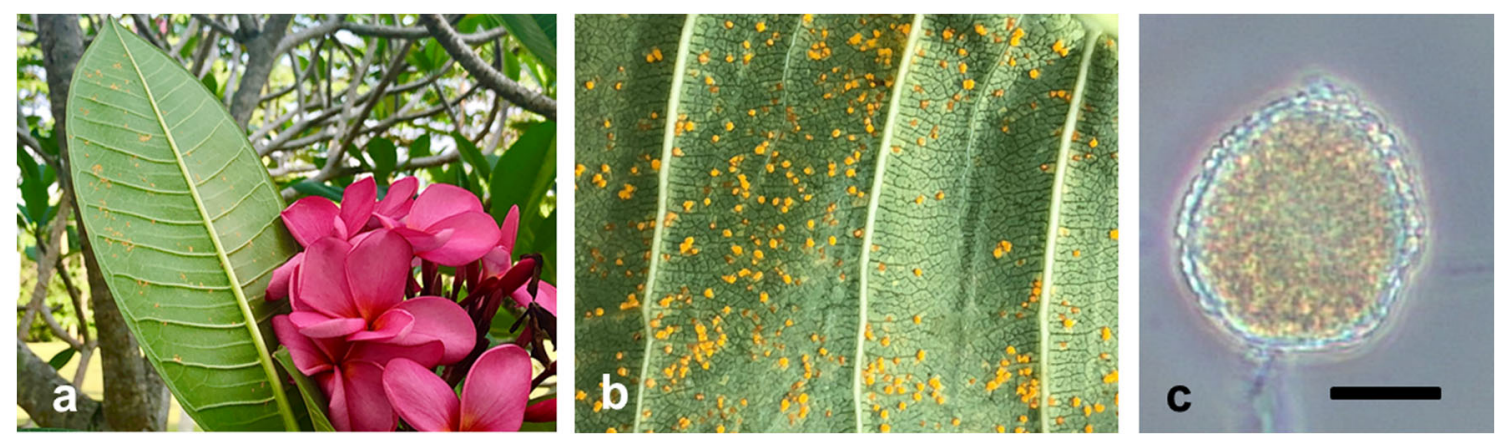

Fig. 1 Symptoms and morphology of plumeria rust caused by Coleosporium plumeriae in Plumeria rubra. a and b - Rust symptoms; $\mathbf{c}-$ Urediniospores. Scale bar $=10 \mu \mathrm{m}$

cotton blue or distilled water and fungal structures were observed and measured using a light microscope. Microscopic examination of infected leaves revealed the presence of urediniospores (Fig. 1c) that were a bright yellow-orange color, ellipsoidal or globose, sometimes angular, echinulate, and measured 16.3-42.2 × 16.4-29.8 $\mu \mathrm{m}$, matching with ranges reported by Traquair and Kokko (1980). Teliospores were not observed in any of the samples collected.

For molecular identification, DNA was extracted from urediniospores of four samples (A1-CARCP01, A2CARCP02, A3-CARCP03 and A4-CARCP04) each obtained from single pustules, following the protocols described by Doyle and Doyle (1987). Amplification of ITS region was performed using ITS1/ITS4 primer (White et al. 1990). PCR amplification was performed according to protocols described by Langrell et al. (2008). Purified DNA was then sent for sequencing (Macrogen Inc., South Korea). Sequences were desposited in GenBank (accession number: MK788144, MK788146, MK788147 and MK788148), with an average of sequence length about $700 \mathrm{bp}$. BLASTn searches in NCBI GenBank showed $100 \%$ identity to sequence of Coleosporium plumeriae from the neighboring country, Malaysia (GenBank accession number: MF769628). Multiple sequence analysis (MSA) was performed with the four isolates from the present study, and compared against other nucleotide sequences from GenBank. Austropuccinia psidii (EF210142) was used as an outgroup taxon (Table 1) based on ClustalW (Thompson et al. 1994). Phylogenetic analyses were performed in MEGA6 (Tamura et al. 2013) using the maximum-likelihood method with additional 1000
Table 1 Details of Colesoporium plumeriae isolates from Plumeria rubra and other rust fungi used in the phylogenetic analyses in this study

\begin{tabular}{|c|c|c|c|c|}
\hline Species & Isolate code & Host & Locality & $\begin{array}{l}\text { ITS-rDNA Accession } \\
\text { number }\end{array}$ \\
\hline $\begin{array}{l}\text { Coleosporium } \\
\text { plumeriae }\end{array}$ & A1-CARCP01 & Plumeria rubra & Riau, Indonesia & MK788144 ${ }^{\mathrm{a}}$ \\
\hline $\begin{array}{l}\text { Coleosporium } \\
\text { plumeriae }\end{array}$ & A2-CARCP02 & Plumeria rubra & Riau, Indonesia & MK788146 ${ }^{\mathrm{a}}$ \\
\hline $\begin{array}{l}\text { Coleosporium } \\
\text { plumeriae }\end{array}$ & A3-CARCP03 & Plumeria rubra & Riau, Indonesia & MK788147 ${ }^{\mathrm{a}}$ \\
\hline $\begin{array}{l}\text { Coleosporium } \\
\text { plumeriae }\end{array}$ & A4-CARCP04 & Plumeria rubra & Riau, Indonesia & MK788148 ${ }^{\mathrm{a}}$ \\
\hline $\begin{array}{l}\text { Coleosporium } \\
\text { plumeriae }\end{array}$ & MCA3480 & Plumeria sp. & Sabah, Malaysia & MF769628 \\
\hline $\begin{array}{c}\text { Coleosporium } \\
\text { solidaginis }\end{array}$ & MCA3473 & Solidago sp. & $\begin{array}{l}\text { Solidago, North } \\
\text { America }\end{array}$ & MF769632 \\
\hline $\begin{array}{l}\text { Coleosporium } \\
\text { campanulae }\end{array}$ & IT7AG & $\begin{array}{l}\text { Campanula } \\
\quad \text { rapuncoloides }\end{array}$ & Turin, Italy & KY296542 \\
\hline $\begin{array}{l}\text { Coleosporium } \\
\text { zanthoxyli }\end{array}$ & KUS-F29608 & $\begin{array}{l}\text { Zanthoxylum } \\
\text { planispinum }\end{array}$ & South Korea & MH465095 \\
\hline $\begin{array}{l}\text { Coleosporium } \\
\text { euodiae }\end{array}$ & - & $\begin{array}{l}\text { Tetradium } \\
\quad \text { glabrifolium }\end{array}$ & P. R. China & KP017557 \\
\hline $\begin{array}{l}\text { Coleosporium } \\
\text { cimicifugatum }\end{array}$ & - & Cimicifuga sp. & P. R. China & KP017559 \\
\hline Austropuccinia psidii & UFV-9 & Eucalyptus sp. & $\begin{array}{l}\text { Tasmania, } \\
\text { Australia }\end{array}$ & EF210142 \\
\hline
\end{tabular}

${ }^{\text {a }}$ Submitted in this study 
Fig. 2 Phylogram of maximumlikelihood analysis based on internal transcribed spacer region of rDNA (ITS) of four

Coleosporium plumeriae isolates from this study (indicated by gray background) together with other sequences retrieved from GenBank. An isolate of Austropuccinia psidii was used as outgroup taxon. Bootstrap values greater than $80 \%$ are shown as percentages of 1000 replicates

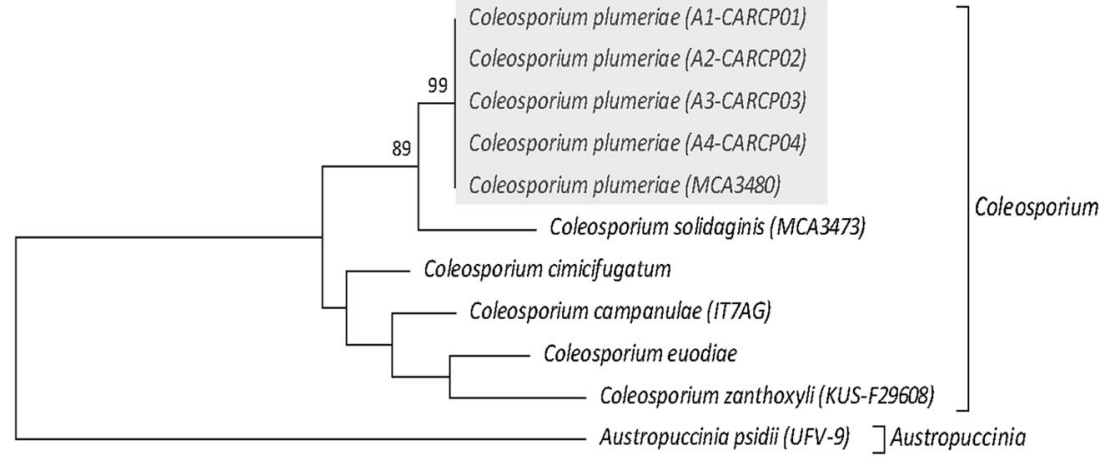

0.02 bootstrap replications to increase accuracy on phylogenetic tree topology. Phylogenetic analyses showed that four isolates grouped on the same clade of Coleosporium plumeriae, with high bootstrap support of $99 \%$ (Fig. 2).

Inoculations were performed on young plants of $P$. rubra. Three month-old plants were transplanted into 3 L capacity polybags containing a mixture of cocopeat (80\%) and carbonized rice husk (20\%) and kept under growth chamber with controlled temperature and humidity $\left(25^{\circ} \mathrm{C} / 80 \%\right)$. Two months later, plants were inoculated by spraying an inoculum suspension at $2 \times 10^{4}$ spores $/ \mathrm{mL}$ in water containing $1 \%$ Tween 20. Plants were covered with black plastic bags to ensure darkness for the first $24 \mathrm{~h}$. The plastic bags were then removed and plants were kept for additional $72 \mathrm{~h}$ in the same growth chamber with photoperiod of $12 \mathrm{~h}$. Inoculated plants were then moved to open area until observation of first symptoms. To complete the requirements of Koch's postulate, urediniospores were collected from inoculated plants and morphological features were compared with those of the inoculum. Typical rust symptoms were observed on inoculated P. rubra plants while non-inoculated plants used as control remained asymptomatic throughout the entire experiment. Urediniospores collected from inoculated plants had the same morphological features and DNA sequences as those originally collected from naturally infected plants, fulfilling the Koch's postulates for obligate pathogens (biotrophic).

Observations of natural infections as well as inoculations conducted under controlled conditions showed that $P$. rubra is hightly susceptible to $C$. plumeriae isolates collected in Pangkalan Kerinci, Riau, Sumatra. This pathogen has a very specific host range, affecting species of the genus Plumeria, but has also been reported on Catharanthus roseus, also in the Apocynaceaee (Holcomb and Aime 2010). Host reactions among Plumeria spp. and hybrids range from highly susceptible to highly resistant (Nelson 2009).

Other than genetic resistance, integrated practices can be applied to reduce new infections and consequently minimize the disease impact. In this case, removal and elimination infected leaves from underneath the canopy early in the season combined with pruning of infected leaves still attached to the branches are important practices to reduce the source of inoculum. Infected fallen leaves may serve as inoculum source once the spores can survive on leaf debris and then spread by the wind. Additionally, hyperparasites have been reported infecting urediniospores of $C$. plumeriae (Manimohan and Mannethody 2011) and potential biocontrol could function as an alternative component of integrated management. Chemical control is also an alternative (Nelson 2009). To avoid the spread of $C$. plumeriae into disease free areas, restriction of the movement of infected plant material and quarantine measures should be considered.

Acknowledgements We thank Asia Pacific Resources International Holdings Ltd. (APRIL) for financial assistance that made this study possible. We also thank Dr. MJ Wingfield whose suggestions helped improve the submitted manuscript.

\section{References}

Arthur JC (1918) Uredinales of Guatemala based on collections by E. W. D. Holway. Am J Bot 5:325-336

Doyle JJ, Doyle JL (1987) A rapid DNA isolation procedure for small quantities of fresh leaf tissue. Phytochem Bull 19(1):11-15

Holcomb GE, Aime MC (2010) First report of Plumeria spp. rust caused by Coleopsporium plumeriae in Louisiana and Malaysia and Catheranthus roseus, a new host of this rust. Plant Dis 94:272

Kakishima M, Ji JX, Zhao P, Wang Q, Li Y, McKenzie EHC (2017) Geographic expansion of a rust fungus on Plumeria in Pacific and Asian countries. N Z J Botan 55(2):178-186

Kobayashi T, Kakishima M, Katumoto K, Oniki M, Nurawan A (1994) Diseases on forest and ornamental trees observed in Indonesia. For Pest 43:43-47

Langrell SRH, Morag G, Alfenas AC (2008) Molecular diagnosis of Puccinia psidii (guava rust) - a quarantine threat to Australian eucalypt and Myrtaceae biodiversity. Plant Pathol 57:687-701

Manimohan P, Mannethody S (2011) Zygosporium gibbum: a new and remarkable rust hyperparasite. Mycosphere 2(3):219-222

Nelson S (2009) Plumeria rust. University of Hawaii at Manoa, cooperative extension service leaflet no. PD-61

Patouillard N (1902) Champignons de la Guadelope. Bull Soc Mycol France 18:171-186 
Tamura K, Stecher G, Peterson D, Filipski A, Kumar S (2013) MEGA6: molecular evolutionary genetics analysis version 6.0. Mol Biol Evol 30(12):2725-2729

Thompson JD, Higgins DG, Gibson TJ (1994) CLUSTAL W: improving the sensitivity of progressive multiple sequence alignment through sequence weighting, positions-specific gap penalties and weight matrix choice. Nucleic Acids Res 22:4673-4680
Traquair JA, Kokko EG (1980) Spore morphology in Coleosporium plumeriae. Can J Bot 58:2454-2458

White TJ, Brun T, Lee S, Taylor J (1990) Amplification and direct sequencing of fungal ribosomal RNA genes for phylogenetics. In: Innis N, Gelfand D, Sninsky J, White TC (eds) PCR protocols and applications - a laboratory manual. Academic Press, New York 